\title{
Puheenvuoro
}

Prologi - puheviestinnän vuosikirja 2017 50-51

\section{Jokaisella ihmisellä on jotain sanottavaa}

\author{
Vuoden 2017 vuorovaikutusteko -palkinto \\ "Kunnanjohtajan osallistuminen mopomiittiin"
}

\author{
Markus Hirvonen \\ kunnanjohtaja, Juuan kunta \\ HTM (oikeustieteet) YAMK (johtaminen) \\ markus.hirvonen@juuka.fi
}

"Jokaisella ihmisellä on jotain sanottavaa" on yksi niistä tärkeistä opetuksista, jonka isäni minulle jo nuorena antoi. Minua ärsytti suunnattomasti tietyssä nuoruuden vaiheessa käydä isäni kanssa esimerkiksi kaupassa, sillä hän pysähtyi jokaisen ihmisen luo ja vaihtoi heidän kanssaan pari sanaa. Ja tarkoitan jokaisen pienen kunnan asukkaan kanssa. Kauppareissulla meni aikaa tunteja. Ihmisen asemalla yhteiskunnassa tai ulkoisella habituksella ei ollut isälleni koskaan merkitystä, vaan opetus oli aina sama: " jokaisella ihmisellä on jotain sanottavaa". Kun sitten kasvoin aikuiseksi, tämä opetus oli iskostunut selkäytimeeni ja siitä oli muodostunut minullekin toimintatapa. Sairaalamaailmassa tämä oli välttämättömyys, koska ihmisen aito kohtaaminen tarkoittaa aitoa vuorovaikutusta, jossa ollaan oikeasti kiinnostuneita ihmisen tahdosta. Hallintotehtäviin siirtymisen jälkeen huomasin jälleen, että aidosta vuorovaikutuksesta toimijoiden kanssa oli hyötyä. Mitä vaikeampi tilanne, sitä enemmän vuorovaikutuksella on merkitystä. Mutta vuorovaikutus ei saa olla toiminnasta erillinen kokonaisuus, vaan sen tulee olla luonnollinen osa kaikkea työtä.

Siksi minulle oli valtava yllätys, mitkä mittasuhteet kesäinen mopoiluiltani sai Suomessa. Söin lasteni kanssa iltapuuroa, kun mopoilijat ajelivat taloani ympäri. Muistin silloin ne lukuisat puhelut ja viestit, jossa kunnanjohtajaa vaadittiin laittamaan mopoilijat kuriin. Kuriin en usko kuin armeijassa, joten hetken mielijohteesta pyysin Facebookissa mopoa lainaan, jotta voisin käydä nuorten kanssa ajelulla ja keskustelemassa. Noin viiden minuutin kuluttua sain WhatsAppissa viestin juukalaiselta nuorelta: " Hei KJ, milloin lähdetään ajelemaan?". Kun sitten kävin ajelemassa nuorten kanssa TV-kameroiden, median ja satojen ihmisten ympäröimänä, tajusin yhden keskeisen ongelman suomalaisessa yhteiskunnasta. 
Meiltä puuttuu nuorten ja johtavien päättäjien välinen aito vuorovaikutus. Kyse ei ollut mopoilusta tai rälläämisestä, vaan siitä että nuoret kokivat tulleensa kuulluksi. Tämä ilmiö toistui yhteydenotoissa, joita sain kaikkialta Suomesta. Erityisesti teini-ikäisten vanhemmat olivat minuun yhteydessä ja helpottuneita siitä, että jossakin kunnan johto oli aidosti kuullut nuoria valituksen ja torumisen sijasta.

Sain itsekin valtavan oppimiskokemuksen yhteiskuntamme tilasta, jossa vuorovaikutus on joko ulkoistettu muille tai siitä on tullut hyvin valikoivaa. Vuorovaikutus nuoriin on ulkoistettu kuntien nuorisotoimelle, vuorovaikutus työttömiin on ulkoistettu työvoimatoimistolle ja vuorovaikutus alkoholisteihin on ulkoistettu sosiaalityöntekijöille. Samaan aikaan kuntien järjestämiin info- tai muihin tilaisuuksiin osallistuu vain kourallinen kuntalaisia. Perinteiset toimintamallit tukevat perinteisiä rakenteita; ne jotka tuntevat järjestelmän ja osaavat navigoida siinä, tulevat kuulluiksi. Se ei missään nimessä tarkoita sitä, ettei ihmisillä olisi mielenkiintoa omaa elinympäristöään kohtaan. Meillä Juuassa mopomiittiin osallistui käytännössä jokainen 15-18 vuotias juukalainen nuori ja jokaisella oli jotain sanottavaa kunnan asioista. Yhteinen toive kaikilla oli, että he saisivat vapaasti olla osa tulevaisuuden kuntaa. Nuorten luokse on mentävä ja heiltä on kysyttävä aidosti, mitä heillä on sanottavaa. Nykynuoret ovat aivan eliittijoukkoa kaikilla mittareilla. He eivät juo, eivät polta eivätkä tee tyhmyyksiä lähellekään niin paljon kuin allekirjoittanut 1990-luvun lopun Enossa. Heissä on oikeasti tulevaisuus, jos haluamme sen kuulla.

Aikaisemmin siis luulin, että kaikki yhteiskunnassa toimivat juuri samalla tavalla. Oli tärkeää oppia, että yhteiskunnan vuorovaikutus ei ole oikeasti hyvällä tasolla. Tämä oppimiskokemus oli suuri, sillä nyt voimme kehittää kunnan toi- mintaa ja viestintää oikeaan suuntaan. Toimintaympäristö tulee tuntea hyvin, ja kuntaympäristössä on paljon patoutunutta sanottavaa kuntalaisilla. Se pitää löytää ja se pitää kuulla, jos halutaan aitoa kehitystä. Tämän vuoksi strategiatyössä olemme luopuneet perinteisistä infoista kokonaan. Teemme asiasta videoita, menemme vanhusyksiköihin, ajelemme mopoilla, käymme nuokkarilla ja kirjastossa keräämässä ihmisten ajatuksia tulevaisuuden Juuasta. Ja lähdemme aina mukaan, jos joku ehdottaa jotakin. Ja mikä tärkeintä, emme koskaan kumoa ihmisen mielipidettä kunnan kehittämisessä. Kaikkea ei voida toteuttaa, mutta jokainen ajatus voidaan aidosti kuulla. Minulla on tästä loistava esimerkki kesältä. Kävin puistossa eräänä päivänä juttelemassa siellä aikaa viettävien alkoholistien kanssa. Heillä oli toive, että he voisivat käyttää kunnan liikuntapaikkoja hiljaisina aikoina omalla porukalla. Luonnollisesti lupasin, sillä siitä ei ole mitään haittaa. Eräänä iltana olin lenkillä ja näin tekonurmikentällä samojen miesten pelaavan palloa. Miesten, jotka eivät olleet vuosikausiin harrastaneet mitään liikuntaa. Ei heistä kukaan olisi tullut kunnantalolle kysymään tätä asiaa. Heidänkin luokseen piti mennä, ja heilläkin oli sanottavaa.

Juuassa meillä on tavoitteena, että jokainen ihminen puhuu hyvää kunnasta riippumatta siitä, asuuko hän kunnassa vai ei. Haluamme säilyttää maineen ihmisen kokoisena ja ihmisläheisenä kuntana maailmassa, jossa yksilön oikeudet ja vastuut ylikorostuvat. Nuorten osalta meillä on aikaa vain 15 vuotta luoda juuret syvälle Juuan multaan. Jos nuori lähtee tyytyväisenä jatko-opintoihin muihin kaupunkeihin, olemme voittaneet. Osa heistä palaa opintojen jälkeen kotikuntaan, osa jää maailmalle. $\mathrm{Ne}$ jotka eivät palaa, ovat myös mainos kuntamme imagosta. Sitä mainosta ei voi ostaa, eikä siihen voi pakottaa. Silti se on paras mainos, koska se ansaitaan aidolla vuorovaikutuksella. 